\title{
A newly developed subcutaneous nodule 15 years after liver transplantation
}

\author{
Soon Kyu Lee", Pil Soo Sung", Seung Kew Yoon \\ Department of Internal Medicine, College of Medicine, The Catholic University of Korea, Seoul, Republic of Korea \\ \#These authors contributed equally to this work. \\ Correspondence to: Seung Kew Yoon, MD, PhD. Department of Internal Medicine, Seoul St. Mary's Hospital, \#222 Banpo-Daero, Seocho-gu, Seoul, \\ 06591, Republic of Korea. Email: yoonsk@catholic.ac.kr.
}

Submitted Aug 21, 2020. Accepted for publication Sep 23, 2020.

doi: 10.21037/hbsn-20-679

View this article at: http://dx.doi.org/10.21037/hbsn-20-679

A 79-year-old man, who had undergone liver transplantation (LT) 15 years ago due to hepatocellular carcinoma (HCC) related to chronic hepatitis $\mathrm{B}$, was referred for a newly developed $2 \mathrm{~cm}$-sized mass on his left cheek (Figure 1A). Alpha-fetoprotein had been within normal range since LT, and the patient had been on $1 \mathrm{mg} /$ day tacrolimus. Positron emission tomography-computed tomography documented a focal ${ }^{18} \mathrm{~F}$-fluorodeoxyglucose uptake in skin lesion (Figure $1 B$ ).

Biopsy results revealed that the pathologic findings of the subcutaneous mass were consistent with metastatic
HCC with negative (upper part) and focally positive (lower part) hepatocyte-specific antigen staining (Figure 1C). Multiphase magnetic resonance imaging also documented a $3.6 \mathrm{~cm}$-sized mass with arterial enhancement in $\mathrm{S} 8$ of the non-cirrhotic transplanted liver (Figure 1D), which was pathologically similar with HCC in skin and HCC in prior explant in that they showed focal HSA positivity, negativity for stemness markers, and Edmondson-Steiner G2. This case suggests that HCC can recur long time after LT, even at the rare sites. 


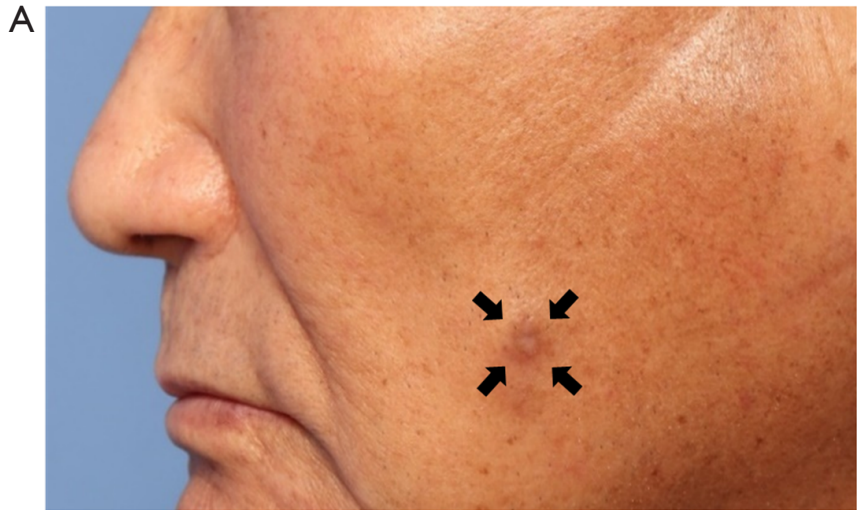

C

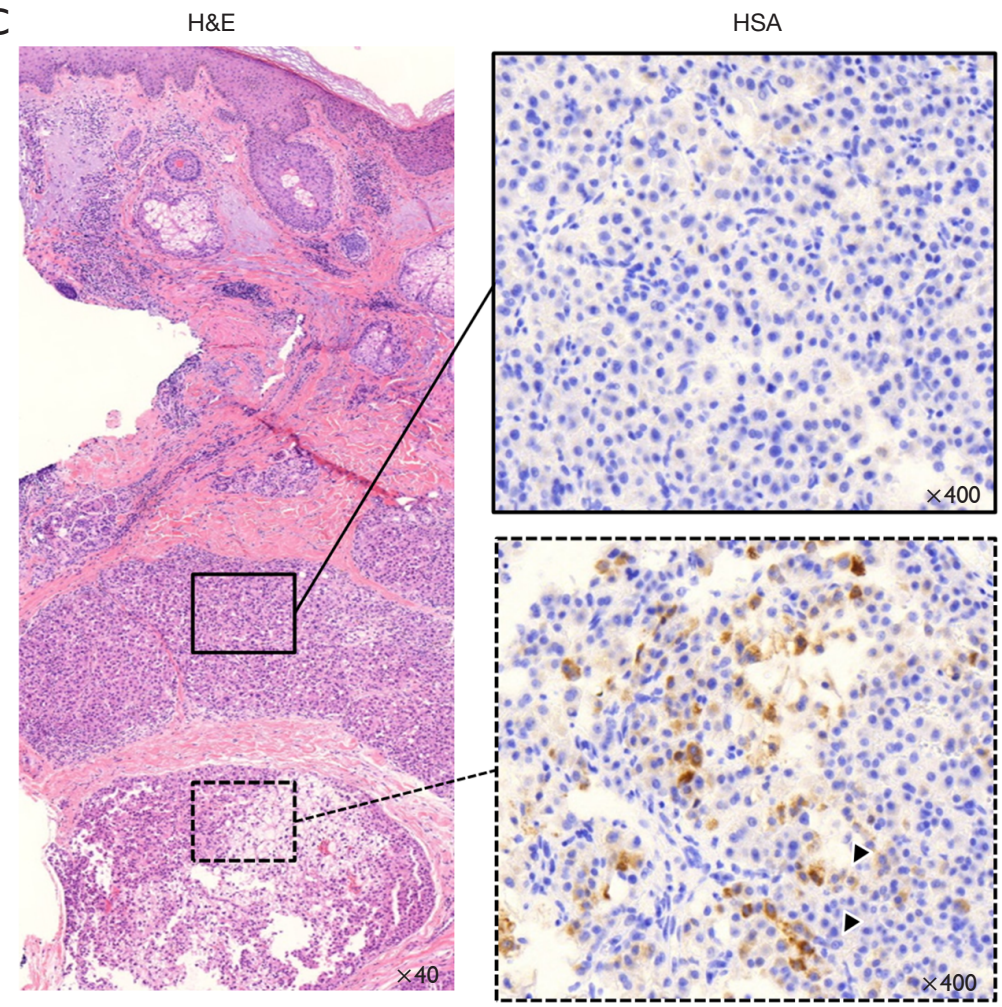

B

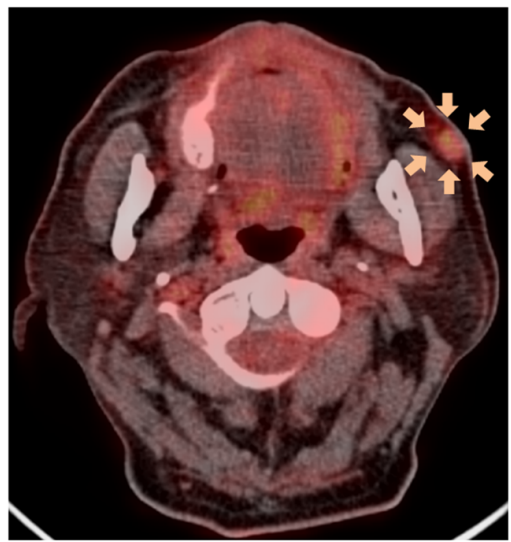

$\mathrm{D}$

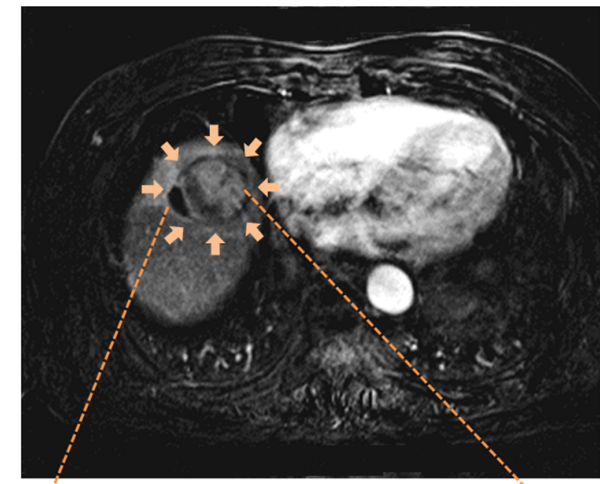

HSA

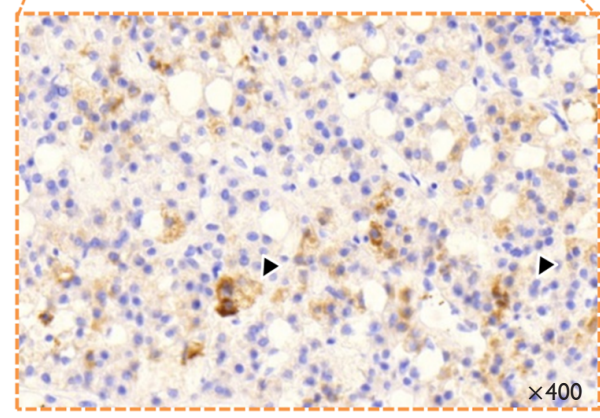

Figure 1 (A) Clinical photo of the skin lesion of the patient. (B) ${ }^{18} \mathrm{~F}$-fluorodeoxyglucose uptake of the skin lesion. (C) Histopathology of the skin biopsy. (D) Image of multiphase magnetic resonance imaging of the liver mass and its biopsy finding. Arrowhead means an HSApositive cell. H\&E, haemotoxylin and eosin; HSA, hepatocyte specific antigen.

\section{Acknowledgments}

Funding: This research was supported by the Basic Science Research Program through the National Research Foundation of Korea (NRF) (NRF2019R1I1A1A01059642).

\section{Footnote}

Provenance and Peer Review: This article was a standard submission to the Hepatobiliary Surgery and Nutrition. The article has undergone external peer review. 
Conflicts of Interest: All authors have completed the ICMJE uniform disclosure form (available at https://hbsn. amegroups.com/article/view/10.21037/hbsn-20-679/coif). Dr. PSS received fund by the Basic Science Research Program through the National Research Foundation of Korea (NRF) (NRF-2019R1I1A1A01059642). The other authors have no conflicts of interest to declare.

Ethical Statement: The authors are accountable for all aspects of the work in ensuring that questions related to the accuracy or integrity of any part of the work are appropriately investigated and resolved.

Open Access Statement: This is an Open Access article distributed in accordance with the Creative Commons Attribution-NonCommercial-NoDerivs 4.0 International License (CC BY-NC-ND 4.0), which permits the noncommercial replication and distribution of the article with the strict proviso that no changes or edits are made and the original work is properly cited (including links to both the formal publication through the relevant DOI and the license). See: https://creativecommons.org/licenses/by-nc-nd/4.0/.

Cite this article as: Lee SK, Sung PS, Yoon SK. A newly developed subcutaneous nodule 15 years after liver transplantation. HepatoBiliary Surg Nutr 2021;10(3):430-432. doi: 10.21037/hbsn-20-679 